\title{
CERAMIDE AND SPHINGOMYELIN LEVELS IN THE RAT BRAIN AFTER CHRYSIN INTAKE
}

\author{
HALINA CAR ${ }^{1,4 \#}$, ANNA FIEDOROWICZ ${ }^{1,2 \#}$, MAŁGORZATA ŻENDZIAN-PIOTROWSKA ${ }^{3}$, \\ ADRIAN CHABOWSKI ${ }^{4}$, SYLWIA K. NALIWAJKO ${ }^{5}$, KATARZYNA SOCHA $^{5}$, RENATA \\ MARKIEWICZ-ŻUKOWSKA ${ }^{5}$, WIOLETA J. OMELJANIUK ${ }^{5}$, MARIA H. BORAWSKA ${ }^{5 *}$ \\ ${ }^{I}$ Department of Experimental Pharmacology, Medical University of Bialystok, Poland \\ ${ }^{2}$ Laboratory of Tumor Molecular Immunobiology, Ludwik Hirszfeld Institute of Immunology and Experimental Therapy, \\ Polish Academy of Sciences, Wroclaw, Poland \\ ${ }^{3}$ Department of Hygiene, Epidemiology and Ergonomics, Medical University of Bialystok, Poland \\ ${ }^{4}$ Department of Physiology, Medical University of Bialystok, Poland \\ ${ }^{5}$ Department of Bromatology, Medical University of Bialystok, Poland \\ *corresponding author: bromatos@umb.edu.pl \\ ${ }^{\#}$ Authors with equal contribution.
}

Manuscript received: November 2018

\begin{abstract}
The pathway of sphingolipid biosynthesis is important in intracellular communication and can be involved in oxidative stress reactions. Natural flavonoids, such as chrysin, present a wide range of antioxidative activities and their ingestion can have many beneficial effects. We studied the levels of ceramides (Cers) and sphingomyelin (SM) in rat brain after 7-day oral administration of chrysin at different doses. Cers and SM lipid fractions containing fatty acids of different chain length and saturation degree were separated by thin-layer chromatography (TLC) and analyzed using gas-liquid chromatography (GLC) technique. We observed the significant changes in the sphingolipid (SF) profiles. Chrysin intake decreased concentrations of Cers containing saturated (SAFA, Cer-C14:0, 16:0, 18:0, 24:0), monounsaturated (MUFA, Cer-C16:1, 24:1) and polyunsaturated fatty acids (PUFA), principally Cer-C18:2, 18:3, 20:4. The levels of SM-SAFA (SM-C14:0, 18:0), -MUFA (SM-C18:1) and -PUFA (SM-C18:2, 20:4, 22:6) were also reduced after the administration of chrysin. We suggest that the decrease in cerebral SF content may be involved in the antioxidative activities of chrysin. The substantial reduction of multiple Cer species levels in the brain may result in diminishing the potential Cers-dependent oxidative stress.
\end{abstract}

\section{Rezumat}

Calea biosintezei de sfingolipide este importantă în comunicarea intracelulară și poate fi implicată în medierea stresului oxidativ. Flavonoidele naturale, cum ar fi crisina, prezintă o serie de activități antioxidante, iar ingestia lor poate avea multe efecte benefice. Au fost studiate nivelurile de ceramide (Cers) și sfingomielină (SM) din creierul de șobolan după administrarea orală, timp de 7 zile de crisină, în doze diferite. Fracțiile lipidice Cers și SM care conțin acizi grași cu lungimea lanţului și grad de saturație diferite au fost separate prin cromatografie în strat subțire (TLC) și analizate prin tehnica cromatografiei gaz-lichid (GLC). S-au observat modificări semnificative ale profilelor sfingolipidelor (SF). Aportul de crisină a scăzut concentrațiile de Cers conținând acizi grași saturați (SAFA, Cer-C14: 0, 16: 0, 18: 0, 24: 0), mononesaturați (MUFA, Cer-C16: 1, 24: 1) și acizi grași polinesaturați (PUFA ), în principal Cer-C18: 2, 18: 3, 20: 4. Nivelurile SM-SAFA (SM-C14: 0, 18: 0), -MUFA (SM-C18: 1) și -PUFA (SM-C18: 2, 20: 4, 22:6) au fost, de asemenea, reduse după administrarea de crisină. Scăderea conținutului cerebral de SF poate influența activitatea antioxidantă a crisinei. Reducerea substanțială a nivelurilor de specii de Cer cerebrale poate duce la diminuarea potențialului stres oxidativ dependent de acestea.

Keywords: chrysin, ceramides, sphingomyelin, brain, rat

\section{Introduction}

Chrysin (5,7-dihydroxyflavone), a natural flavonoid obtained from plant extracts (e.g. Pelargonium crispum P.) [38] and propolis [31] has significant anti-inflammatory effects $[8,16]$ and antihypertensive activity [35]. The anti-cancer properties of chrysin are a result of induction of apoptosis [2, 14, 18, 31, 39] and inhibition of cell proliferation $[31,37]$ in many types of tumour cell lines. It was shown that chrysin possesses anti-inflammatory and anti-oxidative activities in cerebral ischemia/ reperfusion (I/R) injury [40], thus can be considered as a potent neuroprotectant and potentially preventive agent for people at risk of stroke. Furthermore, chrysin exhibits antiaging properties, mainly due to its antioxidant activity $[6,33]$. Up to now, beneficial activities of chrysin toward improving the brain functions, for example in depression and epilepsy, were mainly 
described in relation to its antioxidant activity [21]. In studies on mice subjected to chronic unpredictable mild stress, it was found that chrysin showed antidepressive effect on behavioural, neurotrophic and biochemical parameters similar to fluoxetine. The authors suggested that the up-regulation of brainderived neurotropic factor (BDNF) and nerve growth factor (NGF) levels in mice is a possible mechanism involved in anti-depressive action of chrysin [11]. It has been shown that chrysin remarkably alleviates diabetes-associated cognitive decline (DACD), which suggests that oxidative stress is linked with diabetesassociated cognitive deficits [17]. Che et al. showed that chrysin analogue has strong inhibitory activities against both prostaglandin $\mathrm{E}_{2}$ (PGE2) and NO production [7]. Chrysin can prevent age-associated memory loss probably by its free radical scavenger action and modulation of BDNF production, thus chrysin can be used as an anti-aging agent [33]. It was shown that chrysin has a potential for neuroprotection in epilepsy [9] and Parkinson disease [41].

Oxidative stress may induce signal transduction disturbances, because lipid rafts which are part of cell membranes are very sensitive to superoxide molecules. Lipid rafts contain Cers as functional components of cell membrane. Cers belongs to the sphingolipids (SFs) class and they are composed of a fatty acid chain, with a length ranging from $\mathrm{C} 14$ to $\mathrm{C} 26$ [22] and sphingosine. Cers can be generated by de novo synthesis and degradation of SM. The hydrolysis of SM by sphingomyelinases (SMases): acid SMase, neutral SMase and alkaline SMase, to Cers may have an impact on e.g. membrane microdomain function or vesicular trafficking. Integration of extracellular signalling due to receptor clustering in lipid rafts is facilitated by Cers [34]. Cers level disturbances are observed in many pathological situations. An increase in Cers content was demonstrated in the brains of 7day old mice with ethanol-induced neurodegeneration $[28,29]$. In our previous works $[5,10]$ we showed increased levels of Cers in brains of rats with experimentally induced type 1 diabetes. Accumulation of SM and Cers were detected in spinal cord of Amyotrophic Lateral Sclerosis (ALS) patients and $\mathrm{Cu} / \mathrm{ZnSOD}$ mutant mice. Increased Cers production was also observed in cerebrospinal fluid (CSF) of people with Alzheimer's disease [13], as well as in astroglial cells in the frontal cortex [30] and white matter lesions in rat model of chronic cerebral ischemia [24].

In the present study, we analysed the changes in Cers and SM profiles in the rat brains after administration of chrysin.

\section{Materials and Methods}

\section{Chemicals}

Chrysin (Sigma) dissolved in 1\% methylcellulose was administered by gastric cannula at doses of $25 \mathrm{mg} / \mathrm{kg}$ body weight (bw), $50 \mathrm{mg} / \mathrm{kg} \mathrm{bw}, 100 \mathrm{mg} / \mathrm{kg}$ bw in a volume of $1 \mathrm{~mL} / \mathrm{kg}$ bw [26], once a day, for seven days. $1 \%$ methylcellulose (pH 7.4) as a vehicle was administered by gastric cannula in a volume of 1 $\mathrm{mL} / \mathrm{kg}$ bw per rat.

Animals

32 male Wistar Han (Hannover) rats of 130 - $180 \mathrm{~g}$ bw were used in the experiments. They were obtained from The Centre of Experimental Medicine, Medical University in Bialystok, Poland. Rats were housed in individually ventilated cages (IVC) system, exposed to $12 \mathrm{~h} / 12 \mathrm{~h}$ light/dark cycle beginning at $7.00 \mathrm{~h}$, a temperature of $22 \pm 2{ }^{\circ} \mathrm{C}$ and $55 \%$ relative humidity. Animals were fed standard rat diet and had free access to drinking water. The experiments were performed in accordance with the EU Directive 86/609/EEC and International Guidelines on the Ethical Use of Animals. The Ethics Committee of Medical University in Bialystok, Poland, approved this study [No.1/2010]. Experimental design

In order to determine the effect of chrysin on Cers and SM levels, rats $(n=32)$ were administered three different doses of chrysin. The control group received $1 \%$ methylcellulose as vehicle, whereas experimental groups were fed once a day with chrysin in doses $25 \mathrm{mg} / \mathrm{kg}$ bw, $50 \mathrm{mg} / \mathrm{kg}$ bw, $100 \mathrm{mg} / \mathrm{kg}$ bw for seven consecutive days. The animals' access to food was restricted $12 \mathrm{~h}$ prior the chrysin or vehicle administration. Rats from all groups were sacrificed by lethal anaesthesia, their brains were removed and immediately frozen in liquid nitrogen and stored at $-80^{\circ} \mathrm{C}$ until further use. Analysis of ceramides and sphingomyelin content Cers and SM lipid fractions containing fatty acids of different chain length and saturation degree were separated by TLC and analysed using a GLC technique $[5,10]$. Briefly, the lipid extraction was performed as described by using Bligh and Dyer's method [3] and subsequently Cers and SM were separated by TLC using different solvents for either Cers and SM. After resolving, the bands corresponding to either Cers or SM were scrapped from a plate and mixed with pentadecanoic acid (Sigma) as an internal standard. Further, SFs were transmethylated in methanol at $100^{\circ} \mathrm{C}$ for $90 \mathrm{~min}$, in the presence of $14 \%$ boron trifluoride (SIGMA). The fatty acid methyl esters were analysed by GLC. The concentrations of fatty acids in either Cers or SM lipid fractions were measured by Hewlett-Packard 5890 Series II system equipped with a double flame ionization detector and Agilent CP-Sil 88 capillary column $(100 \mathrm{~m}$, internal diameter of $0.25 \mathrm{~mm}$ ).

\section{Statistical analysis}

The data were analysed using SPSS for Windows, Version 12.0 using two-way analyses of variance (ANOVA). The differences between groups were determined using Kruskal-Wallis test and MannWhitney U test. Results are shown as mean \pm SD. Data are presented as absolute values (nmol/g of tissue) 
or percentage of control; $\mathrm{p}<0.05$ was considered statistically significant.

\section{Results and Discussion}

The percentage of total Cers in cerebral tissue of rats administered with chrysin reached about $60 \%$ of control concentrations for all used doses of this flavone. In contrast, the administration of chrysin did not alter significantly the content of total SM in the brain (Figure 1). Furthermore, we noted that the ingestion of chrysin decreased significantly the amount of all Cers groups (those containing SAFAs, MUFAs and PUFAs) in the brain compared to control, which was observed for all used doses. In contrast, within SM groups, only levels of SM-PUFA were significantly reduced in animal receiving chrysin (Figure 1).

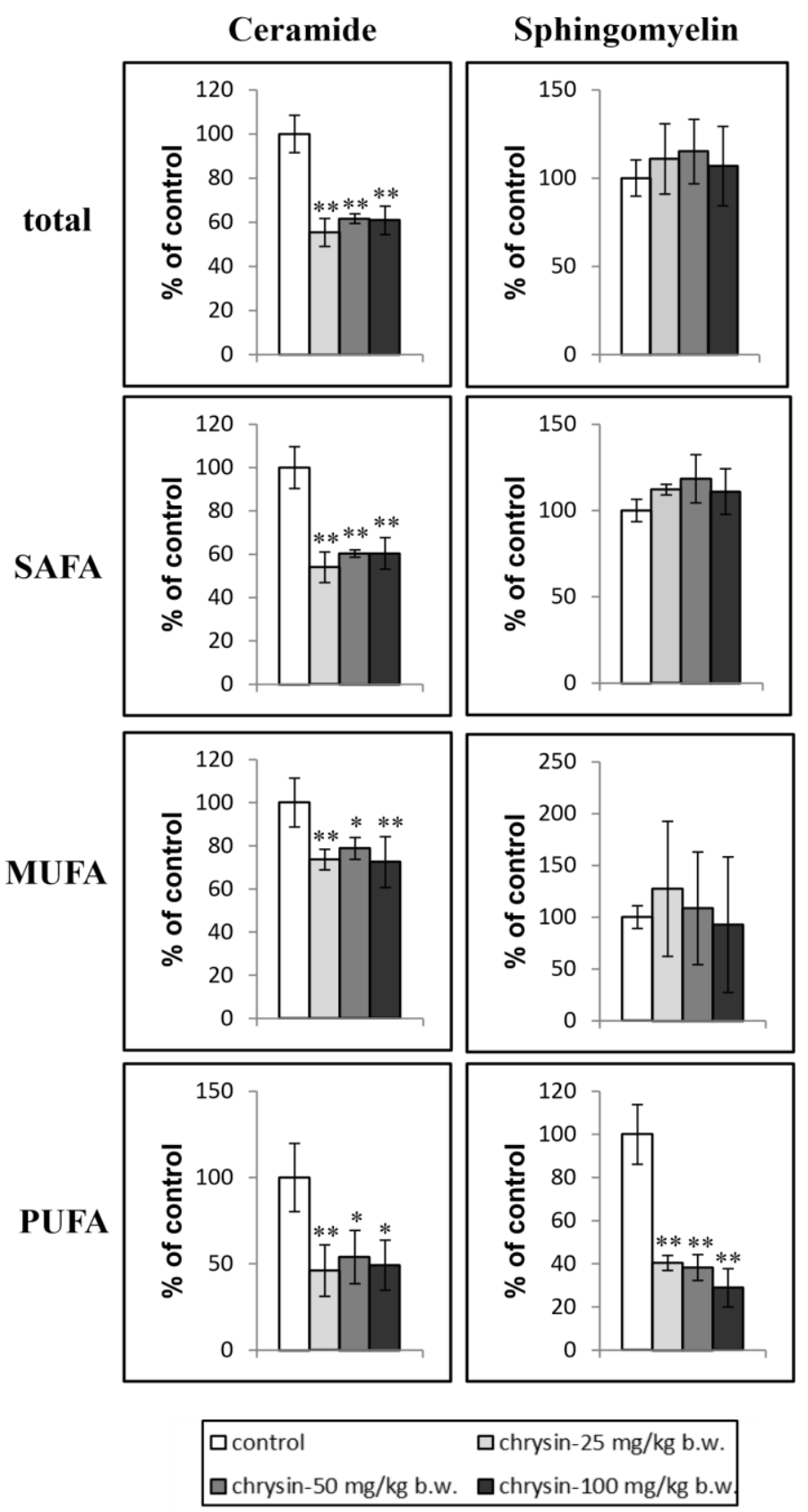

Figure 1.

Total ceramides and sphingomyelin percentage in the brain of rats treated with chrysin All values represent mean $\pm \mathrm{SD}$. $* \mathrm{p}<0.05$ or $* * \mathrm{p}<0.01$, versus control

Among Cers with SAFAs, the most abundant Cers species in the control rat brain contained palmitic fatty acid (C16:0) and stearic fatty acid (C18:0). Chrysin administered at all doses significantly decreased
Cer-C16:0, Cer-C18:0 and Cer-C24:0 content in rat brains in comparison with controls. It should be noted that concentrations of Cer-C20:0 and Cer-C22:0 were not affected after chrysin administration (Table I). 
Concentration of ceramides containing SAFA, MUFA and PUFA in the brain of rats treated with chrysin

\begin{tabular}{|c|c|c|c|c|}
\hline Fatty acid & Control & Chrysin 25 mg/kg bw & Chrysin 50 mg/kg bw & Chrysin $100 \mathrm{mg} / \mathrm{kg} \mathrm{bw}$ \\
\hline \multicolumn{5}{|c|}{ Cer-SAFA (nmol/g tissue) } \\
\hline C 14:0 & $16.41 \pm 3.98$ & $12.35 \pm 1.77$ & $9.25 \pm 1.19$ ** & $14.70 \pm 1.48$ \\
\hline C 16:0 & $154.20 \pm 14.74$ & $78.98 \pm 9.76 * *$ & $83.67 \pm 13.22 * *$ & $92.78 \pm 13.34 * *$ \\
\hline C 18:0 & $324.80 \pm 45.47$ & $170.16 \pm 33.69 * *$ & $204.03 \pm 10.63 * *$ & $194.20 \pm 30.24 * *$ \\
\hline C 20:0 & $18.18 \pm 5.41$ & $17.82 \pm 2.90$ & $17.64 \pm 3.22$ & $15.65 \pm 1.91$ \\
\hline C 22:0 & $9.39 \pm 2.19$ & $10.18 \pm 3.05$ & $9.67 \pm 2.77$ & $8.22 \pm 1.03$ \\
\hline C 24:0 & $28.91 \pm 5.26$ & $8.79 \pm 1.23 * *$ & $8.58 \pm 0.93 * *$ & $7.75 \pm 1.12 * *$ \\
\hline \multicolumn{5}{|c|}{ Cer-MUFA (nmol/g tissue) } \\
\hline C 16:1 & $7.38 \pm 1.08$ & $4.93 \pm 0.34 * *$ & $5.34 \pm 0.78 *$ & $4.71 \pm 0.14 * *$ \\
\hline C 18:1 & $25.31 \pm 4.05$ & $20.77 \pm 2.36$ & $23.97 \pm 3.17$ & $23.53 \pm 4.80$ \\
\hline C 24:1 & $22.73 \pm 3.19$ & $15.11 \pm 3.83 * *$ & $14.37 \pm 2.83 * *$ & $11.92 \pm 1.95 * *$ \\
\hline \multicolumn{5}{|c|}{ Cer-PUFA (nmol/g tissue) } \\
\hline C 18:2 & $2.09 \pm 0.80$ & $1.87 \pm 0.42$ & $2.82 \pm 0.71 * *$ & $3.67 \pm 1.32 *, \#$ \\
\hline C 18:3 & $9.30 \pm 2.10$ & $2.67 \pm 0.17 * *$ & $2.74 \pm 0.71 * *$ & $2.35 \pm 0.62 * *$ \\
\hline C 20:4 & $13.02 \pm 3.32$ & $4.22 \pm 2.10 * *$ & $5.06 \pm 2.18 * *$ & $3.92 \pm 1.79 * *$ \\
\hline C 22:6 & $7.44 \pm 1.90$ & $5.90 \pm 2.23$ & $6.55 \pm 2.45$ & $5.74 \pm 2.32$ \\
\hline
\end{tabular}

All values represent mean \pm SD. ${ }^{*} \mathrm{p}<0.05$ or $* * \mathrm{p}<0.01$, versus control, ${ }^{*} \mathrm{p}<0.05$ versus chrysin $25 \mathrm{mg} / \mathrm{kg}$ bw.

Levels of Cers containing MUFAs, such as palmitoleic acid (C16:1) and nervonic acid (C24:1) were significantly lowered in brain tissues after the intake of all assessed doses of chrysin. The concentrations of Cers with PUFAs (Cer-C18:2, Cer-C18:3, Cer-C20:4) were markedly diminished in the rat brains after chrysin treatment at doses of 50 and respectively $100 \mathrm{mg} / \mathrm{kg} \mathrm{bw}$. Also, chrysin administered at a dose of $25 \mathrm{mg} / \mathrm{kg}$ bw significantly decreased Cer-C18:3 and Cer-C20:4 content in rat brains in comparison with controls. In turn, levels of Cer-C18:2 in brains of rats that ingested chrysin at a dose of $25 \mathrm{mg} / \mathrm{kg}$ bw were lower than those noted when the animals received higher doses of chrysin (Table I). The alterations of SM cerebral content induced by chrysin administration were rather minor. Slight decrements in concentrations of two SM species containing SAFAs, SM-C14:0 and SM-C18:0, were reported when rats were given chrysin at a dose of $50 \mathrm{mg} / \mathrm{kg}$ bw. In contrast, all doses of chrysin significantly reduced levels of SM containing oleic acid (C18:1), which belongs to MUFA group (Table II). After the 7-day administration of chrysin at doses of $25 \mathrm{mg} / \mathrm{kg}$ bw and $50 \mathrm{mg} / \mathrm{kg}$ bw, significant decreases in concentrations SM species containing PUFAs, such: SM-C18:2 and SM-C20:4 were observed in the rat brains. The highest reductions in levels of SM-PUFAs in the brain were reported for SM-C18:2 and SMC22:6 after administration of chrysin at a dose 100 $\mathrm{mg} / \mathrm{kg}$ bw (Table II).

Table II

Concentration of sphingomyelin containing SAFA, MUFA and PUFA in the brain of rats treated with chrysin

\begin{tabular}{|c|c|c|c|c|}
\hline \multirow{2}{*}{ Fatty acid } & \multirow[t]{2}{*}{ Control } & \multicolumn{3}{|c|}{ Chrysin $25 \mathrm{mg} / \mathrm{kg}$ bw Chrysin $50 \mathrm{mg} / \mathrm{kg}$ bw Chrysin $100 \mathrm{mg} / \mathrm{kg}$ bw } \\
\hline & & \multicolumn{3}{|c|}{ SM-SAFA (nmol/g tissue) } \\
\hline C 14:0 & $13.83 \pm 2.72$ & $10.73 \pm 1.89$ & $10.49 \pm 1.61 *$ & $10.96 \pm 1.38$ \\
\hline C 16:0 & $132.74 \pm 21.58$ & $120.49 \pm 5.53$ & $125.24 \pm 14.73$ & $114.21 \pm 22.89$ \\
\hline C 18:0 & $1543.97 \pm 133.40$ & $1687.62 \pm 150.51$ & $1845.17 \pm 166.43 *$ & $1739.24 \pm 239.55$ \\
\hline C 20:0 & $78.14 \pm 6.41$ & $121.37 \pm 48.67$ & $107.42 \pm 45.11$ & $96.65 \pm 27.27$ \\
\hline C 22:0 & $41.85 \pm 8.33$ & $74.17 \pm 46.80$ & $58.27 \pm 35.88$ & $52.63 \pm 26.54$ \\
\hline C 24:0 & $69.21 \pm 11.04$ & $92.59 \pm 56.37$ & $79.29 \pm 31.44$ & $71.18 \pm 42.04$ \\
\hline \multicolumn{5}{|c|}{ SM-MUFA (nmol/g tissue) } \\
\hline C 16:1 & $5.02 \pm 1.28$ & $3.62 \pm 0.65$ & $4.03 \pm 0.75$ & $3.56 \pm 1.25$ \\
\hline C 18:1 & $46.26 \pm 6.51$ & $30.06 \pm 1.30 * *$ & $30.47 \pm 3.77 *$ & $22.52 \pm 6.08 * *$ \\
\hline C 24:1 & $105.97 \pm 12.56$ & $166.63 \pm 102.99$ & $136.27 \pm 81.32$ & $119.83 \pm 99.01$ \\
\hline \multicolumn{5}{|c|}{ SM-PUFA $(\mathrm{nmol} / \mathrm{g}$ tissue $)$} \\
\hline C 18:2 & $46.07 \pm 7.68$ & $3.45 \pm 1.45 * *$ & $3.42 \pm 1.27 * *$ & $2.58 \pm 0.48 * *$ \\
\hline C 18:3 & $2.85 \pm 0.53$ & $3.22 \pm 0.77$ & $3.61 \pm 1.07$ & $3.06 \pm 0.25$ \\
\hline C 20:4 & $7.37 \pm 0.65$ & $9.33 \pm 0.76 * *$ & $8.91 \pm 1.17 *$ & $6.35 \pm 3.03$ \\
\hline C 22:6 & $13.25 \pm 3.16$ & $12.10 \pm 2.36$ & $10.71 \pm 1.17$ & $8.11 \pm 3.32 *$ \\
\hline
\end{tabular}

Oxidative stress is an effect of excessive free-radical production and it is likely implicated as a possible mechanism that involves the initiation and progression of many diseases [25, 27]. Excess of Cers in the brain was observed in various pathological situations [5, 10, 28, 29]. 
Flavonoids can protect the brain from oxidative stress [23]. Chrysin is an important natural plant flavonoid (5,7-dihydroxyflavone) and exerts various pharmacological effects. Several studies demonstrate a positive effect of chrysin on the nervous system. Chrysin given orally at a dose of $400 \mathrm{mg}$ is very quickly absorbed and the peak of plasma chrysin concentration is reached between 30 and 60 minutes [36]. The results of the study by Brown et al. 2007 showed anxiolytic effect of chrysin, 30 minutes after intraperitoneal administration at a dose of $2 \mathrm{mg} / \mathrm{kg}$ bw in rats and suggested very effective kinetics of this flavonoid in the brain [4].

In our study, we have shown that orally administrated chrysin substantially reduced levels of all studied groups of Cers (those containing SAFAs, MUFAs and PUFAs) in the rat brain, already at the lowest dose used. At the same time, chrysin did not exert considerable effects on the SM-SAFA and SM-MUFA brain content, but significantly decreased the least abundant SM form, PUFA-SM.

Cers were studied most frequently for their roles in cytotoxicity. Since over-produced in the Cers-enriched domains, Cers are able to induce an early response to stress stimuli, which includes ROS generation and induction of oxidative stress [19]. The mutual relationship Cers - oxidative stress is however complicated and is presumably based on the loopback regulation. From one side, accumulation of Cers in the cell leads to production of ROS. On the other hand, ROS by themselves increase Cers levels. Thus, the reduction of tissue ROS content by e.g. antioxidants could also influence the concentrations of Cers. Indeed, it was shown that the inhibition of ROS-producing enzymes resulted in acid sphingomyelinase (ASM) downactivation [19]. Similar effects were observed when antioxidants, such as N-acetylcysteine (NAC) and desferrioxamine were applied [32]. Likewise ASM, neutral sphingomyelinase (NSM) was shown to be inhibited by the antioxidants $[1,20]$. In light of those observations, it is not surprising that also chrysin, a strong anti-oxidative agent, modulates Cers levels in the brain, which was found in our work. Focusing on cerebral tissue, which is particularly sensitive to oxidative damage, we postulate that the mechanism of protective activities of antioxidants in the brain can involve the negative regulations of Cers levels. It should be emphasized that the antioxidant intake is common and considered beneficial for the mental condition. Thus, reduction of content of virtually all groups of Cers in healthy brain by chrysin consumption, may act as a sort of preconditioning, which makes neuronal tissue more resistant to prospective stress. Importantly, we found that in contrast to Cers, chrysin did not change significantly the major groups of SM. Consequently, it suggests that chrysin administration does not influence the basic architecture of the cell membranes in the brain. The only exception among
SM forms, which substantially decreased after chrysin consumptions were SM-PUFAs. However, those molecules constitute a tiny population in the neuronal SM content and their decline have rather minor effects on membrane properties. On the other hand, it is well-recognized that polyunsaturated lipids are one of main targets for peroxidation during oxidative insult. Following this line, lowering the SM-PUFAs in cell membrane may enhance its resistance to peroxidation. In summary, the results of our study indicate that the administration of chrysin significantly reduces the amount of Cers containing various fatty acids and SM containing PUFAs in the brain. Unsaturated fatty acids play a number of important functions in the organism, but on the other hand, are more susceptible to oxidation, and therefore oxidative effects $[12,15]$.

\section{Conclusions}

Taken under consideration the present results we can suggest for the first time that chrysin may have a neuroprotective effect against oxidative stress related to changes of content and composition of sphingolipids.

\section{Conflicts of interest}

The authors declare no conflict of interest.

\section{References}

1. Bezombes C, de Thonel A, Apostolou A, Louat T, Jaffrézou JP, Laurent G, Quillet-Mary A, Overexpression of protein kinase Czeta confers protection against antileukemic drugs by inhibiting the redox-dependent sphingomyelinase activation. Mol Pharmacol., 2002; 62(6): 1446-1455.

2. Bielak-Żmijewska A, The mechanism of resistance to apoptosis in tumor cells. Kosmos, 2003; 52(2-3): 157-171, (available in Polish).

3. Bligh EG, Dyer WJ, A rapid method of total lipid extraction and purification. Can J Biochem Physiol., 1959; 37(8): 911-917.

4. Brown E, Hurd NS, McCall S, Ceremuga TE, Evaluation of the anxiolytic effects of chrysin, a Passiflora incarnata extract, in the laboratory rat. AANA J., 2007; 75(5): 333-337.

5. Car H, Zendzian-Piotrowska M, Prokopiuk S, Fiedorowicz A, Sadowska A, Kurek K, Sawicka D, Ceramide profiles in the brain of rats with diabetes induced by streptozotocin. FEBS J., 2012; 279: 1943-1952.

6. Chakraborty T, Perlot T, Subrahmanyam R, Jani A, Goff PH, Zhang Y, Ivanova I, Alt FW, Sen R, A 220-nucleotide deletion of the intronic enhancer reveals an epigenetic hierarchy in immunoglobulin heavy chain locus activation. J Exp Med., 2009; 206(5): 1019-1027.

7. Che H, Lim H, Kim HP, Park H, A chrysin analog exhibited strong inhibitory activities against both PGE2 and NO production. Eur J Med Chem., 2011; 46(9): 4657-4660.

8. Cho H, Yun CW, Park WK, Kong JY, Kim KS, Park Y, Lee S, Kim BK, Modulation of the activity of pro- 
inflammatory enzymes, COX-2 and iNOS, by chrysin derivatives. Pharmacol Res., 2004; 49(1): 37-43.

9. Diniz TC, Silva JC, de Lima-Saraiva SR, Ribeiro FP, Pacheco AG, de Freitas RM, Quintans-Júnior LJ, Quintans Jde S, Mendes RL, Almeida JR, The role of flavonoids on oxidative stress in epilepsy. Oxid Med Cell Longev., 2015; 2015: 1-9.

10. Fiedorowicz A, Prokopiuk S, Żendzian-Piotrowska M, Chabowski A, Car H, Sphingolipid profiles are altered in prefrontal cortex of rats under acute hyperglycemia. Neuroscience, 2014; 256: 282-291.

11. Filho CB, Jesse CR, Donato F, Giacomeli R, Del Fabbro L, da Silva Antunes M, de Gomes MG, Goes AT, Boeira SP, Prigol M, Souza LC, Chronic unpredictable mild stress decreases BDNF and NGF levels and $\mathrm{Na}(+), \mathrm{K}(+)$-ATPase activity in the hippocampus and prefrontal cortex of mice: antidepressant effect of chrysin. Neuroscience, 2015; 289: 367-380.

12. Guéraud F, Atalay M, Bresgen N, Cipak A, Eckl PM, Huc L, Jouanin I, Siems W, Uchida K, Chemistry and biochemistry of lipid peroxidation products. Free Radic Res., 2010; 44(10): 1098-1124.

13. Haughey NJ, Bandaru VV, Bae M, Mattson MP, Roles for dysfunctional sphingolipid metabolism in Alzheimer's disease neuropathogenesis. Biochim Biophys Acta., 2010; 1801(8): 878-886.

14. Izuta H, Shimazawa M, Tazawa S, Araki Y, Mishima $\mathrm{S}$, Hara H, Protective effects of Chinese propolis and its component, chrysin, against neuronal cell death via inhibition of mitochondrial apoptosis pathway in SH-SY5Y cells. J Agric Food Chem., 2008; 56(19): 8944-8953.

15. Kanner J, Dietary advanced lipid oxidation endproducts are risk factors to human health. Mol Nutr Food Res., 2007; 51(9): 1094-1101.

16. Lapidot T, Walker MD, Kanner J, Antioxidant and prooxidant effects of phenolics on pancreatic betacells in vitro. J Agric Food Chem., 2002; 50(25): 7220-7225.

17. Li R, Zang A, Zhang L, Zhang H, Zhao L, Qi Z, Wang H, Chrysin ameliorates diabetes-associated cognitive deficits in Wistar rats. Neurol Sci., 2014; 35(10): 1527-1532.

18. Li X, Huang Q, Ong CN, Yang XF, Shen HM, Chrysin sensitizes tumor necrosis factor-alpha-induced apoptosis in human tumor cells via suppression of nuclear factorkappaB. Cancer Lett., 2010; 293(1): 109-116.

19. Malaplate-Armand C, Florent-Béchard S, Youssef I, Koziel V, Sponne I, Kriem B, Leininger-Muller B, Olivier JL, Oster T, Soluble oligomers of amyloidbeta peptide induce neuronal apoptosis by activating a cPLA2-dependent sphingomyelinase-ceramide pathway. Neurobiol Dis., 2006; 23(1): 178-189.

20. Mansat-de Mas V, Bezombes C, Quillet-Mary A, Bettaïeb A, D'orgeix AD, Laurent G, Jaffrézou JP, Implication of radical oxygen species in ceramide generation, c-Jun $\mathrm{N}$-terminal kinase activation and apoptosis induced by daunorubicin. Mol Pharmacol., 1999; 56(5): 867-874.

21. Nabavi SF, Braidy N, Habtemariam S, Orhan IE, Daglia M, Manayi A, Gortzi O, Nabavi SM, Neuroprotective effects of chrysin: From chemistry to medicine. Neurochem Int., 2015; 90: 224-231.
22. Novgorodov SA, Gudz TI, Ceramide and mitochondria in ischemia/reperfusion. J Cardiovasc Pharmacol., 2009; 53(3): 198-208.

23. Occhiuto F, Palumbo DR, Samperi S, Zangla G, Pino A, De Pasquale R, Circosta C, The isoflavones mixture from Trifolium pratense L. protects HCN 1-A neurons from oxidative stress. Phytother Res., 2009; 23(2): 192-196.

24. Ohtani R, Tomimoto H, Kondo T, Wakita H, Akiguchi I, Shibasaki H, Okazaki T, Upregulation of ceramide and its regulating mechanism in a rat model of chronic cerebral ischemia. Brain Res., 2004; 1023(1): 31-40.

25. Pham-Huy LA, He H, Pham-Huy C, Free radicals, antioxidants in disease and health. Int J Biomed Sci., 2008; 4(2): 89-96.

26. Pushpavalli G, Kalaiarasi P, Veeramani C, Pugalendi $\mathrm{KV}$, Effect of chrysin on hepatoprotective and antioxidant status in D-galactosamine-induced hepatitis in rats. Eur J Pharmacol., 2010; 631(1-3): 36-41.

27. Rahman K, Studies on free radicals, antioxidants, and co-factors. Clin Interv Aging., 2007; 2(2): 219-236.

28. Saito M, Chakraborty G, Hegde M, Ohsie J, Paik SM, Vadasz C, Saito M, Involvement of ceramide in ethanol-induced apoptotic neurodegeneration in the neonatal mouse brain. J Neurochem., 2010; 115(1): 168-177.

29. Saito M, Chakraborty G, Mao RF, Wang R, Cooper TB, Vadasz C, Saito M, Ethanol alters lipid profiles and phosphorylation status of AMP-activated protein kinase in the neonatal mouse brain. J Neurochem., 2007; 103(3): 1208-1218.

30. Satoi H, Tomimoto H, Ohtani R, Kitano T, Kondo T, Watanabe M, Oka N, Akiguchi I, Furuya S, Hirabayashi Y, Okazaki T, Astroglial expression of ceramide in Alzheimer's disease brains: a role during neuronal apoptosis. Neuroscience, 2005; 130(3): 657-666.

31. Sawicka D, Car H, Borawska MH, Nikliński J, The anticancer activity of propolis. Folia Histochem Cytobiol., 2012; 50(1): 25-37.

32. Scheel-Toellner D, Wang K, Assi LK, Webb PR, Craddock RM, Salmon M, Lord JM, Clustering of death receptors in lipid rafts initiates neutrophil spontaneous apoptosis. Biochem Soc Trans., 2004; 32(Pt.5): 679-681.

33. Souza LC, Antunes MS, Filho CB, Del Fabbro L, de Gomes MG, Goes AT, Donato F, Prigol M, Boeira SP, Jesse CR, Flavonoid Chrysin prevents age-related cognitive decline via attenuation of oxidative stress and modulation of BDNF levels in aged mouse brain. Pharmacol Biochem Behav., 2015; 134: 22-30.

34. van Blitterswijk WJ, van der Luit AH, Veldman RJ, Verheij M, Borst J, Ceramide: second messenger or modulator of membrane structure and dynamics? Biochem J., 2003; 369: 199-211.

35. Villar IC, Jiménez R, Galisteo M, Garcia-Saura MF, Zarzuelo A, Duarte J, Effects of chronic chrysin treatment in spontaneously hypertensive rats. Planta Med., 2002; 68(9): 847-850.

36. Walle T, Otake Y, Brubaker JA, Walle UK, Halushka $\mathrm{PV}$, Disposition and metabolism of the flavonoid chrysin in normal volunteers. Br J Clin Pharmacol., 2001; 51(2): 143-146.

37. Weng MS, Ho YS, Lin JK, Chrysin induces G1 phase cell cycle arrest in C6 glioma cells through inducing 
FARMACIA, 2020, Vol. 68, 1

p21Waf1/Cip1 expression: involvement of p38 mitogenactivated protein kinase. Biochem Pharmacol., 2005; 69(12): 1815-1827.

38. Williams CA, Harborne JB, Newman M, Greenham J, Eagles J, Chrysin and other leaf exudate flavonoids in the genus Pelargonium. Phytochemistry, 1997; 46(8): 1349-1353.

39. Woo KJ, Jeong YJ, Park JW, Kwon TK, Chrysininduced apoptosis is mediated through caspase activation and Akt inactivation in U937 leukemia cells. Biochem Biophys Res Commun., 2004; 325(4): 1215-1222.
40. Yao Y, Chen L, Xiao J, Wang C, Jiang W, Zhang R, Hao J, Chrysin protects against focal cerebral ischemia/ reperfusion injury in mice through attenuation of oxidative stress and inflammation. Int J Mol Sci., 2014; 15(11): 20913-20926.

41. Zhang Z, Li G, Szeto SS, Chong CM, Quan Q, Huang C, Cui W, Guo B, Wang Y, Han Y, Michael Siu KW, Yuen Lee SM, Chu IK, Examining the neuroprotective effects of protocatechuic acid and chrysin on in vitro and in vivo models of Parkinson disease. Free Radic Biol Med., 2015; 84: 331-343. 